\title{
Kontribusi Bimbingan dan Konseling dalam Mengembangkan Kesadaran Beragama Pada Remaja di Abad 21
}

\author{
Edisa Oktonika ${ }^{1}$ \\ ${ }^{1}$ Bimbingan Dan Konseling, Sekolah Pascasarjana \\ Universitas Pendidikan Indonesia, Jl. Dr. Setiabudi No.229 Kota Bandung, 40154 \\ Penulis untuk Korespondensi/E-mail: edisaoktonika@gmail.com
}

\begin{abstract}
Abstrak - Pada abad ke 21, kenakalan remaja semakin mengkhawatirkan. Saat ini, banyak ditemukan kenakalan remaja yang bukan lagi disebut kenakalan remaja biasa, namun perilaku penyimpangan kenakalan yang dilakukan remaja telah melanggar hukum dan norma yang berlaku di masyarakat. Terjadinya fenomena kenakalan remaja tersebut menjadi bukti dari remaja sekarang telah jauh dari nilai-nilai moral dan kurangnya kesadaran hidup beragama. Kesadaran beragama pada diri remaja merupakan peran yang sangat penting dalam pengembangan moral mereka, karena nilai-nilai moral yang datang dari agama itu stabil dan konstan, kesadaran beragama juga tidak hanya mendasari perilaku yang terlihat, tetapi juga mewarnai sikap, pikiran dan keinginan. Penelitian ini bertujuan untuk mengembangkan kesadaran padada remaja di abad 21. Metode yang digunakan dalam penelitian ini adalah studi kepustakaan, Studi pustakaan merupakan serangkaian kegiatan yang berkenaan dengan metode pengumpulan data. Penelitian dilaksanakan di SMP Negeri 12 Bandung. Populasi pada penelitian ini adalah peserta didik kelas VIII tahun ajaran 2019/2020. Pengambilan sampel penelitian ini dengan cara purposive sampling yang bertujuan agar sampel yang diambil dapat mewakili populasi sehingga diperoleh informasi yang cukup untuk mengestimasi populasinya. Adapun teknik pengumpulan data dalam penelitian ini adalah melalui dokumentasi, yaitu mencari data mengenai hal-hal atau variabel yang berupa catatan, buku, makalah atau artikel. Analisis data adalah metode analisis isi (Content Analysis). Strategi yang dapat digunakan untuk mengembangkan potensi keberagamaan remaja yaitu metode keteladanan, metode pembiasaan, metode menasehati, metode pengamat dan pengawasan. dengan strategi tersebut diharapkan remaja berkembang kesadaran beragama sesuai fitrah-Nya.
\end{abstract}

Abstract - In the 21st century, juvenile delinquency is increasingly worrying. Nowadays, there are many juvenile delinquents who are no longer called juvenile delinquents, but the behavior of juvenile delinquency has violated the laws and norms prevailing in the society. The phenomenon of juvenile delinquency is evidence that adolescents are now far from moral values and lack of awareness of religious life. Religious awareness in adolescents is a very important role in their moral development because moral values that come from religion are stable and constant, religious awareness also not only underlies visible behavior but also colors attitudes, thoughts, and desires. This study aims to develop awareness in adolescents in the 21 st century. The method used in this research is the study of literature, the study of literature is a series of activities relating to the method of data collection. The study was conducted at 12th Junior High School Bandung. The population in this study were students of class VIII in the 2019/2020 school year. A Sampling of this study by means of purposive sampling that aims so that the samples taken can represent the population so that enough information is obtained to estimate the population. The data collection technique in this research is through documentation, which is looking for data about things or variables in the form of notes, books, papers or articles. Data analysis is a content analysis method. Strategies that can be used to develop the potential for adolescent religious diversity are exemplary, habituation, counseling, observer and supervisory methods. With this strategy, it is expected that adolescents develop religious awareness according to nature. 


\section{PENDAHULUAN}

$\mathrm{M}$ asyarakat pada saat ini hidup dalam modernitas yang percaya akan rasionalitas, akan tetapi masih memegang ajaran agamanya secara kuat. Hal tersebut salah satunya disebabkan karena modernitas itu sendiri tidak selalu memberi perbaikan bagi kondisi umat manusia, dan juga modernitas sebagai bagian dari proyek kemajuan rasionalitas, nyatanya hanya memberikan konstribusi positif bagi kelas yang dominan. Mereka-mereka yang terpinggirkan mengalami marginalisasi atau keterasingan dari kemajuan zaman. Selain itu, perkembangan ilmu pengetahuan dan teknologi, serta praktik-praktik kehidupan politik dan ekonomi yang tidak berlandaskan moral agama telah menyebabkan berkembangnya gaya hidup (life style), materialistik, dan hedonistik di kalangan warga masyarakat. Dampak lebih jauhnya dari gaya hidup tersebut adalah merebaknya dekadensi moral atau pelecehan nilai-nilai agama, baik dikalangan orang dewasa, remaja, maupun anak-anak.

Pada abad 21 ini sama-sama diketahui bahwa tidak semua remaja peduli tentang agama, ada yang benar-benar mempelajari dan ingin tahu banyak tentang agama, ada juga yang sama sekali tidak mau tahu tentang agama. Agama yang merupakan pengendali tingkah laku yang baik bagi manusia terkadang diabaikan begitu saja dengan alasan hidup itu harus selalu mengikuti perkembangan zaman. Saat ini banyak beredar berita-berita di TV, surat kabar, radio serta media sosial lainnya tentang berbagai permasalahan yang dialami oleh remaja seperti tindak kekerasan, penyalahgunaan narkoba, tauran pelajar, pelecehan seksual dan lain sebagaianya. perkembangan remaja juga telah menjadi sorotan utama yang banyak kita temui dalam berbagai aspek lingkungan sehari-hari. Baik dalam lingkungan masyarakat, lingkungan sekolah, lingkungan teman sebaya, dan juga lingkungan keluarga. Menurut Piaget [1] secara psikologis masa remaja merupakan usia seorang individu berintegrasi dengan masyarakat dewasa, usia dimana anak tidak lagi merasa di bawah tingkatan orang-orang yang lebih tua melainkan berada dalam tingkatan yang sama, sekurang-kurangnya dalam masalah hak. Integrasi dalam masyarakat (dewasa) mempunyai banyak aspek efektif, kurang lebih berhubungan dengan masa puber. Termasuk juga perubahan intelektual yang khas dari cara berpikir remaja memungkinkan remaja untuk mencapai integrasi dalam hubungan sosial orang dewasa, yang merupakan ciri khas dari periode perkembangan remaja.

Pada periode remaja ini, bisa dikatakan masa dimana segala sesuatu dengan mudah dibentuk dan akan sangat menentukan bagaimana kelanjutanya dimasa yang akan datang. Masa remaja sebenarnya merupakan perpanjangan masa kanak-kanak sebelum mencapai masa dewasa, karena masa remaja merupakan masa peralihan yang ditempuh oleh seseorang dari kanak-kanak menuju dewasa. Menurut Harold Alberty dalam [2] periode masa remaja itu kiranya dapat artikan secara umum sebagai suatu periode dalam perkembangan yang dijalani seseorang semenjak berakhirnya mengakhiri kanak-kanaknya dan persiapan memasuki kedewasaanya.

Kesadaran Beragama sudah sepatutnya diintegrasikan ke dalam konseling dalam upaya mengubah pola pikir yang berkembang di akhir abad 21 yaitu mengintegrasian pendekatan psikoterapi (konseling) yang holistik/komprehensif. Bagi klien keyakinan dan praktek beragama merupakan aspek fundamental dalam budayanya, bila konselor memperhatikan hal itu akan meningkatkan efektifitas kinerja konselor. Pendekatan bimbingan dan konseling yang terintegrasi didalamnya dimensi agama, sehubungan dengan itu [3] mengutip pendapat Marsha Wiggins Frame, mengemukakan agama sepatutnya mendapat tempat dalam praktek-praktek konseling atau psikoterapi, alasannya: Para klien pada umumnya memiliki latar belakang agama yang membentuk sikap. keyakinan, perasaan dan tingkah laku. [4] mengungkapkan bahwa keyakinan agama individu harus dipertimbangkan jika keragaman budaya dan nilai di antara individu harus dihormati, dan menunjukkan bahwa keyakinan dan nilai agama memiliki tempat yang sah dalam komponen multikultural dari kurikulum pendidikan konselor.

Landasan religius dalam bimbingan konseling pada dasarnya ingin menetapkan klien yang menjadi fokus sentral upaya bimbingan dan konseling sebagai makhluk Tuhan dengan segenap kemuliaan dan keterbatasannya memerlukan suatu pengarahan yang jelas dalam penyelesaian masalahnya, untuk itu pembahasan dalam bab ini disertai dengan bahasan upaya pentingnya pengintegrasian nilainilai agama dalam proses bimbingan konseling.

Berdasarkan pengamatan ketika melaksanakan internsip di sekolah SMP Negeri 12 kota bandung, 
peneliti menemukan gambaran permasalahan siswa yang berkaitan dengan kesadaran beragama dimana ketika saat analisis ITP, pada salah satu kelas belajar yang beranggotakan 31 orang siswa, ditemukan bahwa aspek butir ITP terendah ada pada aspek landasan hidup religius, berikut data hasil pengolahan ITP pada siswa di SMPN 12 kota bandung.

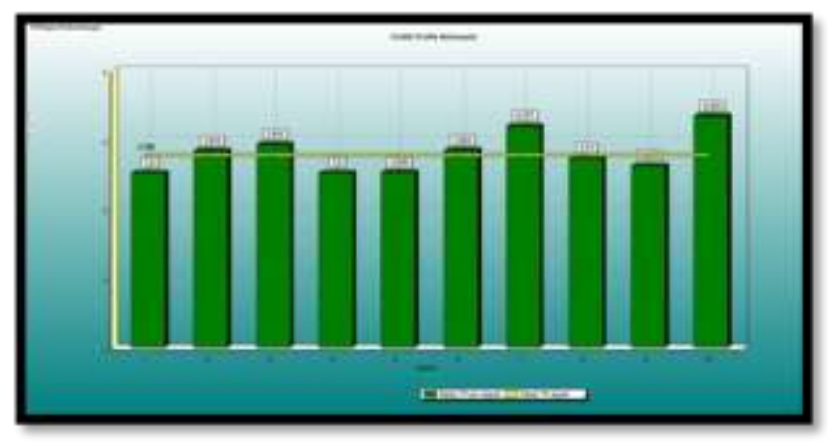

Gambar 1. Grafik Analisis Inventori Tugas Perkembangan (Profil kelompok)

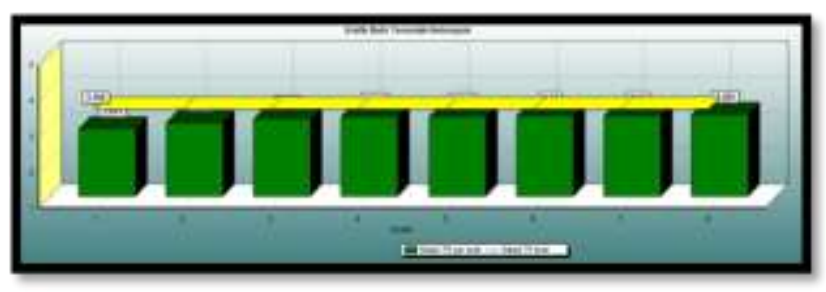

Gambar 2. Grafik Analisis Inventori Tugas Perkembangan (Profil Kelompok)

Tabel 1. Aspek Butir Terendah Siswa Kelas

\begin{tabular}{lcc}
\hline \multicolumn{1}{c}{ Aspek } & Butir & TP \\
\hline Landasan hidup religius & 01-Mar & 2.97 \\
Kesadaran Tanggung Jawab & 05-Mar & 3.10 \\
Kematangan Intelektual & 04-Mar & 3.13 \\
Peran sosial sebagai pria atau wanita & 06-Apr & 3.16 \\
Kesadaran Tanggung Jawab & 05-Jan & 3.26 \\
Landasan Hidup religious & 01-Jan & 3.39 \\
Wawasan dan Persiapan Karir & 09-Feb & 3.42 \\
Peran sosial sebagai pria atau wanita & 06-Mar & 3.42 \\
\hline
\end{tabular}

Kemudian dari hasil wawancara dengan salah satu guru bimbingan dan konseling, di lingkungan sekolah dalam kurung waktu 2 tahun terakhir sering ditemukan siswa yang melanggar norma-norma agama seperti mencuri, minum minuman keras, menonton video porno ketika jam pelajaran berlangsung, melakukan kekerasan terhadap teman seperti bertengkar kemudian ada yang menggunakan kekerasan, pacaran diluar batas bahkan ada siswa yang hamil diluar nikah, berjudi, memakai pakaian ketat serta banyak siswa yang tidak mengikuti kegiatan keagamaan yang diselenggarakan setiap jum'at (lebih memilih nongkrong di kantin sekolah).

Pada setting sekolah, komponen pendidikan yang ada di sekolah seperti guru mata pelajaran, guru pembimbing, tenaga admnistrasi sekolah serta kepala dan wakil kepala sekolah bertanggung jawab untuk mengarahkan siswa kearah yang positif seperti menaati peraturan-peraturan sekolah dan norma agama yang berlaku. Pada pendidikan formal ini, guru mata pelajaran dan guru agama khususnya merupakan ujung tombak dalam proses penanaman nilai-nilai agama pada siswa. Selain guru agama dan guru mata pelajaran lainnya, guru pembimbing juga menduduki posisi penting bagi pengembangan keagamaan siswa. Adanya kerjasama antara guru mata pelajaran dan guru pembimbing hendaknya dapat menumbuh kembangkan kesadaran beragama siswa.

Pesatnya perkembangan zaman pasti akan menimbulkan permasalahan-permasalahan yang semakin kompleks dalam sendi-sendi kehidupan manusia. Hal ini semakin menuntut lahirnya layanan-layanan untuk menyempurnakan kehidupan manusia. Perkembangan ilmu bimbingan konseling sangat dipengaruhi oleh kebutuhan manusia dalam kehidupan yang semakin kompleks. (Komalasari, dkk dalam [5]) mengatakan perkembangan bimbingan konseling tidak hanya berhenti disitu, tetapi terus mendapatkan perhatian bahkan semakin dibutuhkan oleh masyarakat. Dalam upaya tersebut Bimbingan dan Konseling yang merupakan bagian integral dalam sistem pendidikan nasional dan sejalan dengan tujuan pendidikan yang komprehensif memiliki peranan sebagai pendekatan preventif terhadap tantangantantangan yang akan menghambat perkembangan remaja.

Mengingat diperlukan adanya pemahaman tentang kesadaran beragama pada diri remaja, dalam artikel ini akan menjelaskan bagaimana kontribusi bimbingan dan konseling dalam mengembangkan kesadaran beragama pada remaja di abad 21, karena kesadaran beragama merupakan salah satu aspek penting dalam kehidupan manusia.

\section{METODE}

Metode penelitian yang digunakan dalam penelitian ini adalah studi kepustakaan, Studi pustaka dapat dikatakan merupakan suatu serangkaian kegiatan 
yang berkenaan dengan metode pengumpulan data yang dalam hal ini adalah pustaka, membaca dan mencatat serta mengolah bahan penelitian [6]. Akan tetapi, studi pustaka tidak hanya kegiatan yang melakukan pengumpulan, membaca dan mencatat literatur/buku-buku yang difahami banyak orang. Menurut [7] Penelitian kepustakaan perlu memperhatikan langkah-langkah dalam meneliti kepustakaan, harus memperhatikan metode penelitian dalam rangka mengumpulkan data, membaca dan mengolah bahan pustaka serta peralatan yang harus dipersiapkan dalam penelitian tersebut, kegunaannya mempermudah peneliti dalam mendapatkan data.

Penelitian dilaksanakan di SMP Negeri 12 Bandung. Sedangkan yang menjadi populasi pada penelitian ini adalah peserta didik kelas VIII tahun ajaran 2019/2020. Dalam pengambilan sampel penelitian yaitu dengan cara purposive sampling. Sampel merupakan perwakilan dari populasi yang hasil penelitiannya dapat menggeneralisasikan populasi [8]. Purposive sampling bertujuan agar sampel yang diambil dapat mewakili populasi sehingga diperoleh informasi yang cukup untuk mengestimasi populasinya.

Proses pelaksanaan studi kepustakaan adalah proses yang melalui tahapan-tahapan dimana pemilihan topik, eksplorasi informasi, menentukan fokus penelitian, pengumpulan sumber data, persiapan penyajian data, dan penyusunan laporan. Adapun teknik pengumpulan data dalam penelitian ini adalah melalui dokumentasi, yaitu mencari data mengenai hal-hal atau variabel yang berupa catatan, buku, makalah atau artikel, jurnal dan sebagainya [9]. Dan analisis data adalah metode analisis isi (Content Analysis), Analisis ini digunakan untuk mendapatkan inferensi yang valid dan dapat diteliti ulang berdasarkan konteksnya [10].

\section{HASIL DAN PEMBAHASAN}

Agama bisa dikatakan merupakan pedoman hidup atau petunjuk bagi kehidupan manusia yang merupakan ikatan yang kuat serta dapat diyakini akan membawa ke jalan yang lurus serta menunjukkan kepada suatu jalan untuk mencapai kebahagian, ketenangan, ketentraman, serta kemantapan hati. Pengertian agama telah dibuat oleh para ahli, di antaranya ada yang mengemukakan bahwa agama identik dengan religion dalam bahasa Inggris. Endang S. Anshari [11] mengemukakan bahwa sebagian filosof beranggapan tentang religion itu merupakan supertitious structure of incoherent metafhisical nations, kemudian sebagian ahli sosiologi lebih senang menyebut religion sebagai collective expression of human values, dan para pengikut Karl Max mendefinisikan religion dengan the opiate of the people.

Nottingham [12] mengatakan bahwa agama merupakan suatu gejala yang begitu sering "terdapat di mana-mana", selain itu juga agama berkaitan dengan usaha-usaha manusia dalam mengukur makna dari keberadaan diri sendiri dan keberadaan alam semesta. Kesadaran beragama pada manusia itu ditunjukan dengan adanya keinsyafan sehingga tercipta suasana yang bernuansa agama dalam kehidupan sehari-hari, baik dalam lingkungan rumah tangga maupun dalam lingkungan masyarakat. Dengan demikian, kesadaran beragama dapat dikategorikan kedalam segi aqidah, akhlaq, dan dari segi sosialnya.

Kesadaran beragama dari segi aqidah

Kesadaran beragama dalam arti segi aqidahnya adalah sikap rohaniyah seperti ingat kepada tuhan, jika didalam islam seperti melaksanakan sholat, mentadarrus al Quran serta lainnya yang diilhami oleh tuntunan ajaran Islam, misalnya berpikir sebagai konsekwensi adanya potensi akal. Jadi dalam kehidupan beragama, setiap orang mengekspresikan dalam kehidupannya di dunia ini suatu pola pikir yang bernilai ibadah atau sesuai dengan ajaran agama.

Kesadaran beragama dari segi akhlaq

Adanya suasana yang kondusif dan bernilai ibadah, sebagai manifestasi dari sikap mental masyarakat yang terjabarkan dalam kehidupannya sehari-hari sebagai dorongan moral yang diilhami iman dan taqwa terhadap tuhan, sehingga segala tindakan, perbuatan bahkan ucapan dan berpikir mempunyai nilai ibadah. Dengan sendirinya sikap moral yang demikian, maka manusia selalu berlomba-lomba dalam kebajikan dimana dan kapan saja. Jadi dari segi akhlak kehidupan beragama, manusia senantiasa berbuat kebaikan dalam kehidupannya, baik untuk kepentingan pribadi, keluarga, bangsa dan negara maupun demi kepentingan agamanya.

Kesadaran beragama dari segi sosial.

Dalam hidup ber-masyarakat, maka setiap manusia dituntut mempunyai kepedulian terhadap lingkungan sekitarnya, oleh karena itu dalam kesadaran beragama, senantiasa terjalin hubungan yang harmonis dan timbal balik antara satu dengan 
yang lainnya, baik kepada masyarakat pada umumnya maupun secara khusus kepada ke dua orang tuanya. Dengan adanya saling toleran antara satu dengan yang lainnya, maka timbul rasa saling tolong menolong,

Bertitik tolak dari uraian di atas tentang kesadaran beragama, manusia memiliki keinsyafan dan kesadaran beragama, baik dari segi aqidah dan akhlaq maupun dari segi sosialnya. Dengan demikian, kesadaran beragama meliputi rasa keagamaan, pengalaman ke-Tuhanan, keimanan, sikap, dan tingkah laku keagamaan, yang terorganisasi dalam sistem mental dari kepribadian. Karena agama melibatkan seluruh fungsi-jiwa manusia, maka kesadaran beragama pun mencakup aspek-aspek afektif, konatif, kognitif dan motorik. Keterlibatan fungsi afektif dan konatif terlihat dalam pengalaman ke-Tuhanan, rasa keagamaan dan rindu kepada Tuhan. Aspek kognitif nampak dalam keimanan dan kepercayaan. Sedangkan keterlibatan fungsi motorik nampak dalam perbuatan dan tingkah laku keagamaan. Dalam kehidupan sehari-hari, aspek tersebut sukar dipisahkan karena merupakan suatu sistem kesadaran beragama yang utuh dalam kepribadian seseorang [13].

\section{Perkembangan Kesadaran Beragama Pada Remaja}

Goldman [14] pernah melakukan studi tentang perkembangan pemahaman agama pada anak-anak dan remaja dengan melatarbelakangi teori perkembangan kognitif Piaget, yang mengugkapkan bahwa perkembangan kesadaran agama pada remaja berada pada tahap formal operational religious thought, di mana anak atau remaja tersebut memperlihatkan pemahaman agama yang lebih abstrak dan hipotetis. Gmunder [14] mengungkapkan bahwa remaja yang berusia sekitar 17 atau 18 tahun akan semakin meningkat juga tentang kebebasan, pemahaman, dan pengharapan ketika membuat pertimbangan tentang agama.

Perkembangan kesadaran beragama pada remaja erat kaitanya dengan dengan masa menemukan identitas diri, meneliti sikap hidup yang lama dan mencoba sikap hidup yang baru untuk menjadi pribadi yang dewasa. Perkembangan agama pada remaja ditandai oleh beberapa faktor perkembangan rohani dan jasmaninya. Perkembangan itu antara lain menurut W. Starbuck [12] sebagai berikut:
Pertumbuhan Pikiran dan Mental

Ide dan dasar keyakinan beragama yang diterima remaja dari masa kanak-kanaknya sudah tidak begitu menarik bagi mereka. Sifat kritis terhadap ajaran agama mulai timbul. Selain masalah agama mereka pun sudah tertarik pada masalah kebudayaan, sosial, ekonomi dan norma-norma kehidupan lainnya.

\section{Perkembangan Perasaan}

Berbagai perasaan telah berkembang pada masa remaja. Perasaan sosial, etis dan estetis mendorong remaja untuk menghayati peri kehidupan yang terbiasa dalam lingkungannya. Kehidupan religius akan cenderung mendorong dirinya lebih dekat ke arah hidup yang religius pula.

\section{Pertimbangan Sosial}

Corak keagamaan pada masa remaja juga ditandai oleh adanya pertimbangan sosial. Dalam kehidupan agama mereka, timbul konflik antara pertimbangan moral dan material sehingga mereka sangat bingung menentukan pilihan itu. Karena kehidupan duniawi lebih dipengaruhi kepentingan materi, para remaja cenderung bersikap materialis.

\section{Perkembangan Moral}

Perkembangan moral pada remaja bertitik tolak dari rasa berdosa dan usaha untuk mencari proteksi.

\section{Sikap dan minat}

Sikap dan minat remaja terhadap masalah keagamaan boleh dikatakan sangat kecil dan hal ini tergantung dari kebiasaan masa kecil serta lingkungan agama yang mempengaruhi mereka (besar kecil minatnya).

$\underline{\text { Ibadah }}$

Remaja yang menganggap sembahyang hanyalah merupakan media untuk bermeditasi lebih banyak daripada remaja yang mengatakan sembahyang bermanfaat untuk berkomunikasi dengan Tuhan.

Penghayatan para remaja terhadap ajaran agama dan tindak keagamaan yang tampak pada para remaja banyak berkaitan dengan faktor perkembangan diatas. Daradjat (Wahab, 2015 :113) sikap atau ciri khas remaja terhadap agama adalah percaya turut-turutan, percaya dengan kesadaran, percaya tapi agak ragu-ragu, dan tidak percaya sama sekali atau cenderung pada atheis. 
Berdasarkan pendapat ahli tersebut sikap tau ciri khas keberagamaan remaja yang pertama adalah percaya turut-turutan, para remaja dalam mempercayai adanya Tuhan dan menjalankan ajaran agama pada awalnya mengikuti apa yang ada pada lingkungannya yaitu meneruskan dari masa anak - anak dalam hal ini adalah lingkungan keluarga, kemudian diteruskan dengan lingkungan sekolah dan masyarakat. Percaya turut-turutan ini biasanya tak lama, pada umumnya terjadi pada masa remaja awal (13-16 tahun). Setelah itu akan terjadi perkembangan kearah jiwa yang lebih kritis dan lebih sadar.

Kedua percaya dengan kesadaran, sebagaimana yang telah dijelaskan diatas kesadaran atau semangat keagamaan pada masa remaja dimulai dengan kecenderungannya untuk meninjau dan meneliti ulang cara ia beragama dimasa kecil dulu. Semangat keagamaan itu biasanya terjadi setelah usia 17 tahun, mulai berbentuk yaitu apakah timbul semangat positif dan semangat hurafi. Semangat agama positif berusaha melihat agama dengan pandangan yang kritis, tak mau lagi menerima halhal yang tak masuk akal. Pandangan seperti itu membangkitkan rasa aman pada remaja terhadap agamanya. Semangat agama hurafi adalah kecenderungan berpikir kekanak-kanakan, biasanya cenderung mengambil unsur-unsur luar dan mencampurkannya kedalam agama dan keyakinannya, remaja yang seperti ini cenderung mengajak orang lain untuk mempercayai keyakinannya itu dan bahkan ia menjadikannya sebagai alat pergaulan dalam masyarakat.

Ketiga percaya tapi agak ragu-ragu, sesungguhnya kebimbangan yang terjadi pada remaja terhadap ajaran agama yang pernah diterima dimasa kecilnya merupakan pertanda bahwa kesadaran agama sudah terasa oleh remaja. Tentunya kemampuan merasa ragu-ragu terhadap apa yang diterimanya begitu saja berhubungan erat dengan pertumbuhan kecerdasan yang dimilikinya. Biasanya, kebimbangan itu mulai menyerang remaja setelah pertumbuhan kecerdasan mencapai kematangannya, sehingga ia dapat mengkritik, menerima, atau menolak apa saja yang diterangkan kepadanya.

Keempat tidak percaya sama sekali atau cenderung pada atheis, ketidakpercayaan yang sungguhsungguh tidak terjadi sebelum usia 20 tahun. Perkembangan ke arah tidak percaya pada Tuhan sebenarnya bersumber pada masa kecilnya, bila seorang anak merasa tertekan atas kekuasaan atau kezaliman orang tua, maka ia telah menyimpan atau memendam sesuatu tantangan terhadap kekuasaan orang tua, selanjutnya berlaku terhadap kekuasaan apapun termasuk terhadap kekuasaan Tuhan.

\section{Kebutuhan Manusia akan Agama}

Manusia memiliki berbagai bentuk kebutuhan, tidak hanya kebutuhan fisik dan biologis seperti makan, minum, dan kebutuhan jasmaniah lainnya, manusia juga perlu memenuhi kebutuhankebutuhan psikis yang bersifat rohaniah. Agama sebagai pedoman hidup bagi manusia telah memberikan petunjuk tentang berbagai aspek kehidupan atau pengembangan mental (rohani) yang sehat. Sebagai petunjuk hidup bagi manusia dalam mencapai mentalnya yang sehat. Menurut Daradjat [15] kebutuhan-kebutuhan tersebut adalah sebagai berikut.

\section{Kebutuhan Akan Rasa Kasih Sayang}

Rasa kasih sayang merupakan kebutuhan jiwa yang paling mendasar dalam hidup manusia. Kebutuhan akan rasa kasih sayang dapat dipenuhi seseorang dengan percaya kepada Tuhan dan betul-betul meyakini Maha Pengasih dan Maha Penyayang kepada umat-Nya.

\section{Kebutuhan Akan Rasa Aman}

Setiap manusia memerlukan rasa aman, tentram dan bebas dari ketakutan. Hilangnya rasa aman akan berpengaruh negatif pada dirinya sehingga ia akan ketakutan berlebihan bahkan akan menaruh prasangka buruk dan curiga terhadap orang lain. Namun, jika individu tersebut memiliki keimanan yang kuat, dia akan senantiasa berserah diri sehingga muncul perasaan aman dan dilindungi oleh Allah SWT dalam kondisi dan situasi apapun.

\section{Kebutuhan Akan Rasa Harga Diri}

Setiap orang butuh dihargai dan ingin diperhatikan. Orang-orang yang beriman dan percaya pada Tuhan walau dalam kehidupannya kurang mendapat penghargaan dari orang lain, akan tetapi dia tidak pernah terusik karena ada Tuhan yang mengangkat derajat orang-orang yang beriman.

\section{Kebutuhan Akan Rasa Bebas}

Kehilangan rasa bebas menyebabkan seseorang menjadi gelisah, tertekan baik fisik maupun psikis. Orang yang beriman tidak akan pernah merasa hilang kebebasannya sekalipun ia terkungkung dan terkurung dalam ruangan yang gelap dan pengap karena ia yakin tidak ada yang mampu mengungkung hatinya selain Tuhan. 
Kebutuhan Akan Rasa Sukses

Bagi orang-orang yang beriman, kalaupun keinginannya atau usahanya tidak berhasil, dia tidak akan merasa kecewa dan putus asa justru akan menjadi termotivasi agar lebih giat dalam berdo'a dan berusaha.

\section{Kebutuhan Akan Rasa Ingin Tahu}

Secara kasat mata kita juga tahu bahwa manusia sejak lahir memiliki rasa ingin tahu yang kuat tetapi tidak semua rasa ingin tahu itu bisa dijawab dan diketahui melalui ilmu pengetahuan dan daya nalar. Karena memang Allah tidak hanya menciptakan syahadah saja, namun juga ada alam gaib, yang tidak bisa dijangkau dengan pengetahuan ilmiah. Untuk memuaskan rasa ingin tahu manusia terhadap hal yang sulit dijangkau dengan akal, Allah telah menurunkan Al-Qur'an sebagai pedoman hidup yang abadi bagi umat manusia.

Dalam perkembangan manusia, tidak semua pemenuhan kebutuhan tersebut akan mudah dicapai jika individu memiliki kesadaran beragama, karena dengan melaksanakan ajaran agama manusia akan merasa kasih sayang, rasa aman, dihargai, perasaan bebas, kesuksesan, perasaan ingin tahu akan mudah didapatkan. kesadaran beragama memberikan motivasi kepada individu terutama pada mental yang positif. Senada dengan hal ini, [16] menuliskan bahwa motivasi keagamaan lebih terintegrasi dalam kehidupan sosial. Melalui motivasi keagamaan, maka terlibat dengan hubungan antara religius dan keinginan sosial [17].

Dari uraian di atas telah menjelaskan tentang pentingnya kesadaran agama bagi setiap individu manusia dan terkususnya remaja. Dengan demikian pelayanan bimbingan yang terintegrasi di dalamnya nilai-nilai agama. Terkait dengan pentingnya memperhatikan nilai-nilai agama ini, [18] mengemukakan "bagaimanapun perubahanperubahan sosial budaya tersebut terjadi, maka pendidikan agama hendaknya tetap diutamakan. Sebab darinya terkandung nilai-nilai moral, etik dan pedoman hidup sehat yang universal dan abadi sifatnya."

\section{Metode dan Teknik Bimbingan Konseling}

Ditengah masyarakat yang agamis, pendekatakan bimbingan dan konseling yang berlandaskan agama akan sangat tepat layanan yang diberikan dalam rangka membantu dan berguna bagi permasalahanpermasalahan individu menjalani kehidupan seharihari. Pada beberapa kelompok masyarakat tertentu ada yang pemahaman agamanya bisa dikatakan minim karena beberapa alasan, seperti tidak pernah mendapatkan pengajaran agama yang tepat atau karena degradasi moral akibat benturan dengan paham-paham yang hedonis dan materialistik. Pada kelompok tersebut, pendekatan bimbingan dan konseling dengan landasan agama tidak bisa dipraktekan dengan mudah tetapi harus bertahap dan kemungkinan untuk mendapatkan tolakan harus siap dihadapi oleh seorang konselor.

Ada banyak dan berbagai macam pendekatan dalam bimbingan dan konseling, jika pendekatan bimbingan dan konseling di klasifikasikan sebagai proses komunikasi, maka secara garis besar bisa kelompokan menjadi metode komunikasi langsung atau disingkat metode langsung dan metode komunikasi tidak langsung atau metode tidak langsung.

\section{Metode Langsung}

Metode langsung (metode komunikasi langsung) bisa dikatakan merupakan suatu metode dimana seorang konselor ataupun pembimbing melakukan komunikasi langsung (bertatap muka) dengan orang yang dibimbingnya. Metode ini kemudian dirinci lagi menjadi:

a. Metode individual

Pembimbing melakukan komunikasi langsung secara individual kepada pihak yang dibimbingnya. Hal ini dapat dilakukan dengan mempergunakan teknik:

1) percakapan pribadi, yakni pembimbing melakukan dialog langsung tatap muka dengan pihak yang dibimbing;

2) kunjungan ke rumah (home visit), yakni pembimbing mengadakan dialog dengan kliennya tetapi dilaksanakan di rumah klien sekaligus untuk mengamati keadaan rumah klien dan lingkungannya;

3) kunjungan dan observasi kerja, yakni pembimbing/konseling jabatan, melakukan percakapan individual sekaligus mengamati kerja klien dan lingkungannya.

b. Metode kelompok

Pembimbing melakukan komunikasi langsung dengan klien dalam kelompok. Hal ini dapat dilakukan dengan teknik-teknik:

1) Diskusi kelompok, yakni pembimbing melaksanakan bimbingan dengan cara mengadakan diskusi dengan bersama kelompok klien yang mempunyai masalah yang sama.

2) Karyawisata, yakni bimbingan kelompok yang dilakukan secara langsung dengan 
mempergunakan ajang karyawisata sebagai forumnya;

3) Sosiodrama, yakni bimbingan/konseling yang dilakukan dengan cara bermain peran untuk memecahkan mencegah timbulnya masalah (psikologis);

4) Psikodrama, yakni bimbingan/ konseling yang dilakukan dengan cara bermain peran untuk memecahkan/ mencegah timbulnya masalah (psikologis);

\section{Metode Tidak Langsung}

Metode tidak langsung (metode komunikasi tidak langsung) merupakan suatu metode bimbingan/konseling yang dilakukan oleh konselor atau pembimbing melalui media. Hal ini dapat dilakukan secara individual maupun kelompok, bahkan massal.

a. Metode individual

1) melalui surat menyurat;

2) melalui telepon dsb

3) pemanfaatan media internet

b. Metode kelompok/ massal

1) melalui papan bimbingan;

2) melalui surat kabarl majalah;

3) melalui brosur;

4) melalui radio (media audio);

5) melalui televisi.

Berbagai persyaratan konselor telah banyak diuraikan di buku-buku referensi mengenai konseling. Dalam aplikasinya konselor yang memiliki latar belakang religius dituntut untuk memiliki pemahaman akan nilai-nilai agama dan komitmen yang kuat dalam mengamalkan nilainilai tersebut dalam kehidupan sehari-hari khususnya dalam memberikan layanan Bimbingan dan Konseling bagi klien maupun bagi peserta didik. Harus disadari bahwa layanan bimbingan dan konseling merupkan salah satu kegiatan ibadah sehingga kegiatan tersebut harus didasarkan pada keikhlasan dan kesabaran. [19] mengemukakan persyaratan bagi konselor sebagai berikut :

- Konselor hendaklah orang yang beragama dan mengamalkan dengan baik keimanan dan ketakwaannya sesuai dengan agama yang dianutnya.

- Konselor sedapat-dapatnya mampu mentransfer kaidah-kaidah agama secara garis besar yang relevan dengan masalah klien.

- Konselor harus mampu memperhatikan dan menghormati agama klien.

Kemudian [2], menguraikan kompetensi dasar yang seyogyanya dimiliki konselor sebagai berikut:
- Penguasaan wawasan dan landasan pendidikan

- Penguasaan konsep bimbingan dan konseling

- Penguasaan kemampuan assesment

- Penguasaan kemampuan mengembangkan program bimbingan dan konseling

- Penguasaan kemampuan mengembangkan proses kelompok

- Penguasaan kesadaran etik professional dan pengembangan profesi

- Penguasaan pemahaman konteks budaya, agama dan setting kebutuhan khusus

\section{KESIMPULAN}

Kesadaran beragama merupakan sesuatu yang terasa, yang meliputi pengalaman ke-Tuhanan, keimanan, sikap, dan tingkah laku keagamaan yang disertai penghayatan yang tulus, terorganisasi dalam sistem mental dari kepribadian, dimana kesemuanya itu merupakan wujud dari rasa keterdekatan dengan sesuatu yang lebih tinggi dari segalanya yaitu Tuhan Yang Maha Esa (Allah SWT). Selain itu juga masa remaja merupakan masa pencapaian identitas, bahkan bisa dikatakan perjuangan pokok pada masa remaja adalah antara identitas dan kekacauan peran. Pada waktu remaja menemukan siapa dirinya yang sebenarnya atau identitas diri, tumbuhlah kemampuan untuk mengikat kesetiaan kepada suatu pandangan atau ideologi. Maka dari itu, bila ideologi remaja tidak diarahkan dengan benar maka rentan terkena pengaruh negatif kelompok kultus, sekte dan aliran ideologi berbahaya lainnya.

Konselor harus mempunyai kompetensi untuk mengarahkan potensi keberagmaan remaja agar tidak terjerumus kedalam ideologi yang sesat tersebut. Maka dari itu konselor harus memahami konsep kesadaran beragama remaja. Kesadaran beragama merujuk pada aspek rohaniah individu yang berkaitan dengan keyakinan dan keimanan kepada Allah SWT yang direfleksikan kedalam peribadatan kepada-Nya, baik yang bersifat hablummminallah maupun hablumminannas. Kesadaran beragama remaja berkembang selama rentang kehidupan. Selama proses perkembangannya, kesadaran beragama seseorang dipengaruhi oleh faktor pembawaan dan faktor eksternal diluar diri Individu tersebut. Selanjutnya strategi yang dapat digunakan untuk mengembangkan potensi keberagamaan remaja yaitu metode keteladanan, metode pembiasaan, metode menasehati, metode pengamat dan pengawasan. dengan strategi tersebut diharapkan 
remaja berkembang kesadaran beragama sesuai fitrah-Nya.

\section{REFERENSI}

[1] E. B. Hurlock, Psikologi Perkembangan Suatu Pendekatan Sepanjang Rentang Kehidupan, Jakarta: Erlangga, 2015.

[2] A. J. Nurihsan and M. Agustin, Dinamika Perkembangan anak dan Remaja, Bandung: Refika Aditama, 2011.

[3] S. Yusuf and N. Juntika, Landasan Bimbingan dan Konseling, Bandung: Remaja Rosdakarya, 2014.

[4] R. H. Pate and A. M. Bondi, "Religious beliefs and Practice: An Integral Aspect of Multicultural Awarness," Counsellor Education and Supervision, vol. 32, no. 2, 1992.

[5] S. Hanani, Komunikasi Antar Pribadi, Yogyakarta: Ar-Ruzz Media, 2017.

[6] M. Zed, Metode Penelitian Kepustakaan, Jakarta: Yayasan Obor Indonesia, 2003.

[7] Khatibah, "Penelitian Kepustakaan," Iqra', vol. 05, no. 01, 2011.

[8] J. W. Creswell, Educational Research: Planning, Conducting, And Evaluating Quantitative nad Qualitative Research, Boston: Pearson, 2017.

[9] S. Arikunto, Prosedur Penelitian Suatu Pendekatan Praktik, Jakarta: Rineka Cipta, 2010.
[10] K. Kripendoff, Analisis Isi: Pengantar Teori dan Metodologi, Jakarta: Citra Niaga, 1993.

[11] R. A. Sodikin, "Konsep Agama dan Islam," Jurnal Kajian Keislaman, vol. 20, no. 97, 2003.

[12] Jalaluddin, Psikologi agama, Jakarta: Raja Grafindo Persada, 2008.

[13] A. A. Ahyadi, Psikologi Agama: Kepribadian Muslim Pancasila, Bandung: Sinar Baru Algesindo, 2005.

[14] Desmita, Psikologi Perkembangan Peserta Didik, Bandung: Remaja Rosdakarya, 2014.

[15] R. Wahab, Psikologi agama, Jakarta: Rajawali Pers, 2015.

[16] P. J. Waston; N. Ghorbani; H. K. Davison; M. N. Bing; R. W. Hood; A. F. Ghramaleki, "Personal Extrinsic Motivations: Religious Orientation, Inner Awareness, and Mental Health in Iran and the United States," International Journal for Psychology of Religion, vol. 12, no. 4, pp. 255 - 276, 2002.

[17] T. Hemmati, J. F. Mills and D. G. Kroner, "The Validity of the Bar - On emotional Intelligence quotient in an offender population," Personality and Individual Difference, vol. 37, no. 4, pp. 695-706, 2004.

[18] D. Hawari, Al Qur'an, Ilmu Kedokteran dan Kesehatan Jiwa, Yogyakarta: Dhana Bakti Prima Yasa, 1997.

[19] Prayitno and E. Amti, Dasar - Dasar Bimbingan dan Konseling, Jakarta: PT Rineka Cipta, 2009. 